\title{
ある地方都市の日常生活圈域単位でみた高齢者施設の選択の実態 ACTUAL CHOICES OF FACILITIES FOR THE ELDERLY IN ACCORDANCE WITH 'DAILY LIVING AREAS’ IN A PARTICULAR MUNICIPALITY
}

\author{
西 野 辰 哉* \\ Tatsuya NISHINO
}

\begin{abstract}
This study clarified the actual choices of facilities in accordance with 'daily living areas', which is defined as care service providing districts by local government, in a particular municipality. A case study was conducted for the usage situation of 9 community-based multi-care facilities, 12 group living facilities for the elderly with dementia, and 8 nursing homes in Municipality K, Ishikawa Prefecture. Then, an approximate formulation of the selection rates of these three facilities for the elderly in the living area was made on the basis of the considerations.
\end{abstract}

Keywords : Elderly persons requiring support and long-term care, Facility for the elderly, Daily living areas, Choice 要支援・要介護高齢者, 高齢者施設, 日常生活圈域, 選択

\section{1. 研究の背景と目的, 位置づけ}

超高齢社会に入った日本では、たとえ介護が必要となっても住み 慣れた地域で住み続けられる社会を目指して、介護保険制度と地域 包括ケア政策が実施されている ${ }^{1}$ 。各保険者（主に自治体）は介護 保険事業計画にあたり、地域密着型サービスの計画単位として「日 常生活圈域」を適宜、設定する。これに関連して、広井（2013）は、 これまで福祉政策と都市政策が未連携であったがゆえに福祉政策が 空間的な立地政策の視点を持たなかったことを問題提起している ${ }^{2)}$ 。

高齢者ケアにおいて、この日常生活圈域設定は重要課題の一つで ある。その日常生活圈域毎の需要推計に基づいて地域密着型サービ ス提供施設の供給目標量が設定される。同施設の開設者は保険者で はなく事業者であるため、必ずしも計画上の供給目標量が達成され るとは限らない。従って、現実には介護予防・介護サービス受給者 が自分の居住する日常生活圈域内で同サービスを充足しているとは 限らない。一方、提供されるサービスの質を嗜好して他の日常生活 圈域の施設と契約する場合もありうる。以上より、高齢者福祉施設 の利用圈域の実態を捉えるには、意図的又は結果的な利用者の施設 選択という要素を考慮する必要があるといえる。この施設選択とい う要素を考慮に入れると、より実態に即した供給量の目標設定が可 能となる。しかし保険者レベルでの悉皆的な施設選択の実態は報告 されていない。
そこで本研究の目的は、ある地方都市において日常生活圈域単位 でみた高齢者福祉施設の選択の実態を明らかにし、自らの居住する 日常生活圈域内の施設を選択寸る割合算出の近似式化を試みること である。これにより実態に即した高齢者介護サービス需給量推計手 法を構築しうる点が本研究の意義として挙げられる。

関連研究として、上田ら（1993）が北海道の高齢者の医療受診圈 域と特別養護老人ホームの入所圈域を比較事例考察している ${ }^{3)}$ 。ま た藤本ら（1991）は宇都宮市における福祉圈域設定方法の検討を 行っている ${ }^{4)}$ 。これらは介護保険制度や日常生活圈域設定導入以前 のものである。その後、2000 年に介護保険制度が導入され、2005 年同改正により日常生活圏域設定が導入された。この設定方法につ いて、中山ら（2006）は先行して細分化された福祉サービス提供圈 域を設置していた自治体の圈域階層構造を報告している ${ }^{5)}$ 。さらに 全国自治体（回答数 1,087 / 全自治体 1,840 ）に対する調查をもとに 日常生活圈域設定状況やその目安の実態を明らかにしている（中山 ら，2007） ${ }^{6)}$ 。これらは保険者がどのように日常生活圈域設定を行 うかという視点に立っている。一方、利用者となる高齢者の生活圏 域の視点から、筆者ら（2016）は今回対象市における健康な高齢者 と要支援・要介護高齢者の実態としての生活圈域を市内の全日常生 活圈域にて調査した ${ }^{7)}$ 。これに対して本研究は要支援・要介護高齢 者が高齢者施設をどのように選択しているかについて日常生活圈域

\footnotetext{
*＼cjkstart金沢大学理工研究域環境デザイン学系 准教授・博士(工学)
} 
単位で分析する。また既往研究には小規模多機能型居宅介護事業所 (以下、小規模多機能と略寸)、認知症高齢者グループホーム（以下、 $\mathrm{GH}$ と略す)、介護老人福祉施設（特別養護老人ホーム、以下、特養 と略す）の全事業所・全市的な利用圈域を把握したものはない。即 ち、ある都市の全市的な施設群の利用圈域の実態を日常生活圈域単 位で把握する点に本研究の独自性がある。

\section{2. 研究の方法}

本研究の構成は以下の通りである。以降、特記なき場合、「圈域」 とは「日常生活圈域」を指す。

(1)保険者内圈域単位の施設利用者構成の枠組み、用語、需給量算定 式の定義 $(2-1)$

(2)圈域 $i$ 内 75 歳以上人口 Pi $75+$ と出現施設利用者数 Ui の関係 $(3-1)$ (3)圈域 $\mathrm{i}$ 内施設選択率 $\beta$ i の実態（3-2)

(4)異種施設間の圈域 $\mathrm{i}$ 内施設選択率 $\beta$ i の相関（3-3）

(5)ボロノイ分割による最近隣施設選択率（3-4)

(6)圈域間の移動の実態 (3-5)

(7)圈域 $\mathrm{i}$ 内の施設利用者数 Fi の構成の実態 $(3-6)$

(8)圈域 $\mathrm{i}$ 内施設選択率 $\beta$ i の近似式化 (4)

まず 2-1。で保険者内圈域単位の施設利用者構成の枠組み、用語、 需給量算定式を定義した後、第 3 章以降で(2)～(8)の事例考察を行い、

圈域 $\mathrm{i}$ 内施設選択率 $\beta \mathrm{i}$ 算出の近似式化を試みる。

2-1. 保険者内圏域単位の施設利用者構成の枠組み、用語、需給量算 定式の定義

圏域単位で施設選択の実態を把握するにあたり、保険者内圈域単 位の利用者構成の枠組み、用語、需給量算定式を定義する（図 1,2）。

まずある保険者（例えば K 市を想定）内の圈域 $\mathrm{i}$ 内に居住する高 齢人口Pi（人）から出現する施設利用者数をUi（人）とする（出 現施設利用者数と略す)。また圈域 $\mathrm{i}$ 内の施設利用者率を $\alpha i=\mathrm{ui} /$ Pi $75+$ (利用者率と略す) と寸る。但し、Pi75+は圈域 $i$ 内の 75 歳 以上人口（人）である。75 歳以上人口を用いる理由は、介護保険受 給者数の約 9 割が 75 歳以上であるため、65 歳以上人口を用いるよ り正確な概算が可能だからである ${ }^{8)}$ 注11。

Ui は圈域 i 内の施設利用者数 ui (in)（人）（自圈域内利用者数と 略す) と圈域 i 外の施設利用者数 ui (out)（人）に分かれる。す なわちUi=ui (in) +ui (out) である。Uiのうち自圈域内利用者数 ui (in) の割合 ui (in) / Ui を圈域 i 内施設選択率 $\beta$ i ( 選択率と略寸) とする。

一方、ui (out) の細分類として、K市内の他圈域施設利用者 数 ui (out, inK)（人）とK市外の施設利用者数ui (out, outK) (人)（K市の住所地特例者数とする）に分かれる。すなわち ui (out)=ui (out, inK) +ui (out, outK) である。

さらに圈域 $\mathrm{i}$ 外から来て圈域 $\mathrm{i}$ 内の施設を利用する者の数 0i（人）も存在する。0iの細分類として、K市内他圈域からの 利用者数 oi（inK）（人）とK市外からの利用者数 o i (outK)（人） (他市町村からの住所地特例者数と寸る) に分かれる。すなわち $0 i=0 i(i n K)+o i($ outK) である。地域密着型施設の場合、保険者を跨 いだ利用は現行制度では出来ないので、 $\Sigma$ ui (out, inK $)=\Sigma o i(i n K)$ となる。しかし特養は広域型施設であり、その計画単位は老人福祉 圈域（通常、二次医療圈と同等）のため、保険者を跨ぐ利用、つま

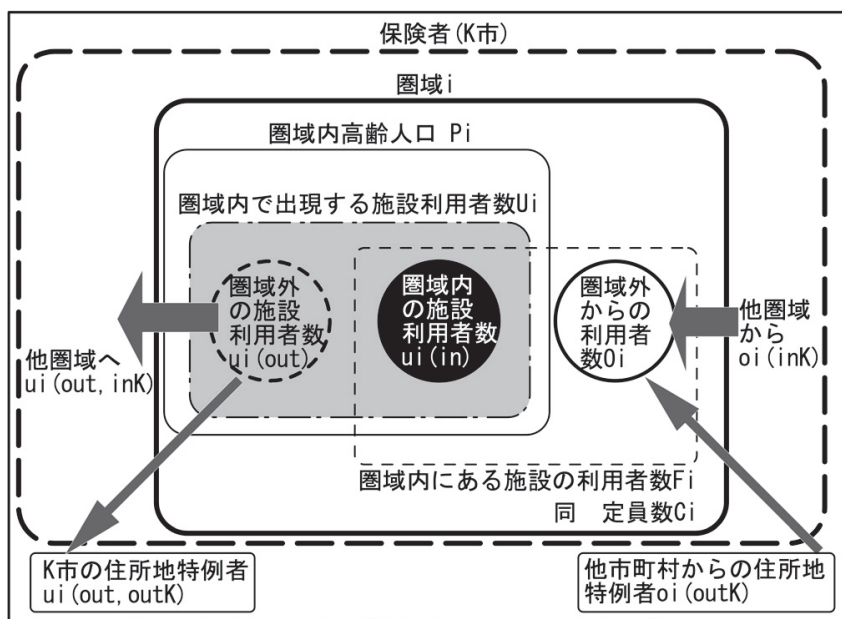

圏域 $\mathrm{i}$ 内施設選択率（選択率） $\beta \mathrm{i}=u \mathrm{i}(\mathrm{in}) / \mathrm{Ui}$

圏域 $i$ 内在率 $($ 内在率 $)=u i(i n) / F i$

圏域 $\mathrm{i}$ 内実態整備率 $($ 実態整備率 $)=\mathrm{Ci} / \mathrm{Ui}$

圈域 $\mathrm{i}$ 内想定整備率 (想定整備率) $=\mathrm{Ci} / \mathrm{Pi} 75+\times \alpha \mathrm{K}$

図 1 保険者内圏域単位の施設利用者構成の枠組みと用語の定義

$\mathrm{Si} \geqq \operatorname{Di}=\operatorname{Pi}(75+) \times \alpha i \times \beta \mathrm{i}$

かつ

Sall $=\sum_{i=1}^{\mathrm{n}} \mathrm{Si}+$ oi $($ outK $)$

$=$ Dall + oi $($ outK $)$

$=\operatorname{Pall}(75+) \times \alpha \mathrm{K}+$ oi $($ outK $)$

但し、

$\mathrm{Si}$ : 圏域 $\mathrm{i}$ 内サービス供給量

$\mathrm{Di}$ :圏域 $\mathrm{i}$ 内サービス需要量

$\mathrm{Pi}(75+)$ : 圏域 $i$ 内 75 歳以上人口

oi (outK) : 保健者 (K市) 外からの 住所地特例者数（広域型のみ）

$\mathrm{n}$ : 日常生活圏域数

Sall: 全圏域サービス供給量

$\beta \mathrm{i}:$ 自圏域内施設選択率

$\mathrm{Dal} \mid$ : 全圏域サービス需要量

$\alpha \mathrm{K}$ : 全圏域利用者率 (対75歳以上人口)

図 2 保険者内圏域単位のサービス需給量の算定式の定義

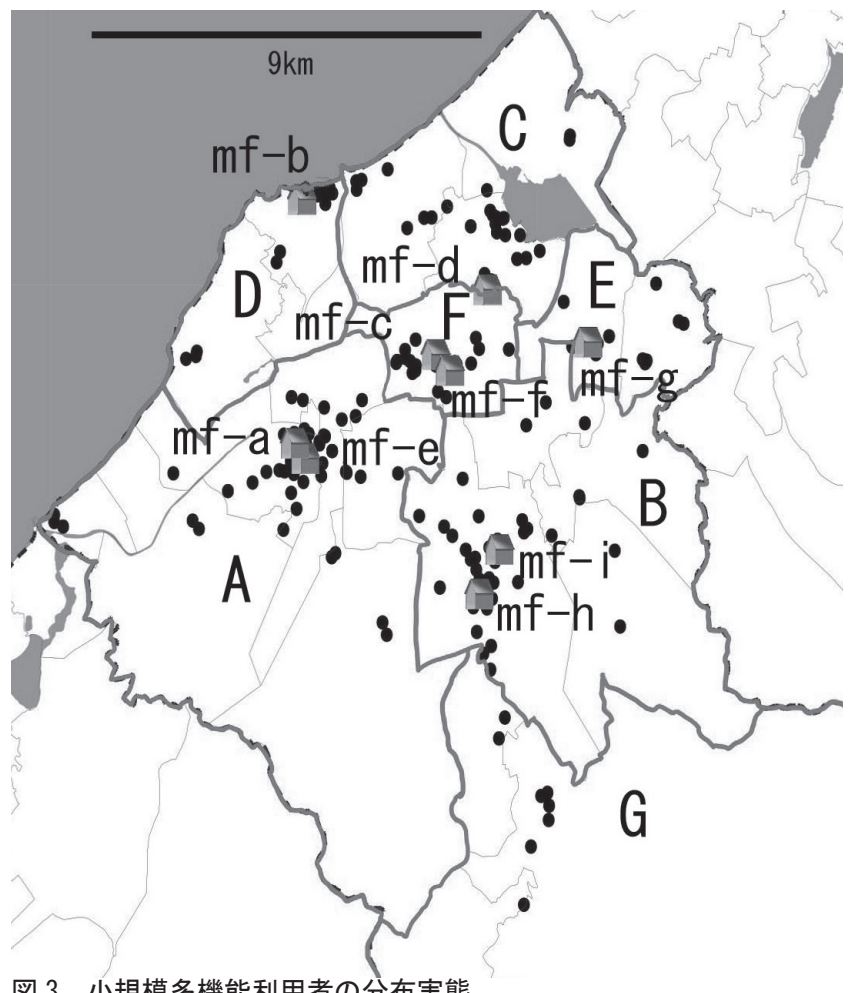

図 3 小規模多機能利用者の分布実態 
り住所地特例者が発生する。

圈域 $\mathrm{i}$ 内にある施設利用者数を Fi (人) (圈域 $\mathrm{i}$ 内の施設利用者 数と略す) とすると、Fi=ui (in) +0i となる。Fi のうち ui (in) の割 合 ui (in) /Fi を圈域 i 内在率（内在率と略す）と寸る。

そして圈域 $\mathrm{i}$ 内にある施設定員数 Ci（人）をUi で除したもの、 すなわち $\mathrm{Ci} / \mathrm{Ui}$ を圈域 $\mathrm{i}$ 内実態整備率（実態整備率と略す）、同じ $<\mathrm{Ci}$ を \{ 圈域 $\mathrm{i}$ 内 75 歳以上人口 P $i 75+\times K$ 市全体の施設利用者率 $\alpha \mathrm{K}$ (=K市内の第一号・第二号被保険者の施設利用者全数) \} で除 したもの、すなわち $\mathrm{Ci} /(\mathrm{Pi} 75+\times \alpha \mathrm{K})$ を圈域 $\mathrm{i}$ 内想定整備率（想 定整備率と略す）とする。

次に図 2 に保険者内圈域単位のサービス需給量の算定式の定義を 示す。ここで定義したのは選択率 $\beta$ i を考慮した実態ベースのサー ビス需給量算定式である。地域密着型サービスの供給目標量算定に 際しては、通常、圈域 i 内で需給充足するように算定するので、選 択率 $\beta$ i $(\times 100)=100 \%$ として計算する。しかし冒頭に述べたと おり、施設選択という要素 $\beta$ i を設定した方が、より実需に近い算 定が可能である。サービス需給量算定において圈域 $\mathrm{i}$ 内施設供給量 は出現利用者数に選択率 $\beta$ i を乗じたもの以上であることが条件と なる。一方、他圈域の施設利用者を考慮すると保険者単位では全利 用者数と同数として上限設定とする。但し、特養は広域型施設であ るため、住所地特例者も考慮しなければならない。つまり、特養は、 制度設計上、選択率 $\beta$ i $(\times 100)$ の理想值は 100\%とはならない。

\section{2-2. 事例対象 K 市の概要と位置付け}

事例対象とする $K$ 市の概要について述べる。K市は石川県の西南 部に位置する面積 $306.00 \mathrm{k} \mathrm{m} \mathrm{m}^{2}$ の地方都市である。北西部は日本海に 面し、南部は中山間地区である。2013.4 時点で総人口 71, 611 人、 65 歳以上人口 20,714 人 ${ }^{9)}$ 、高齢化率が $28.9 \%$ であった。

表 1 に全国と K 市の人口、要支援・要介護認定者数、介護予防・ 介護サービス受給者数、施設利用者数を示す。高齢化率は全国平均

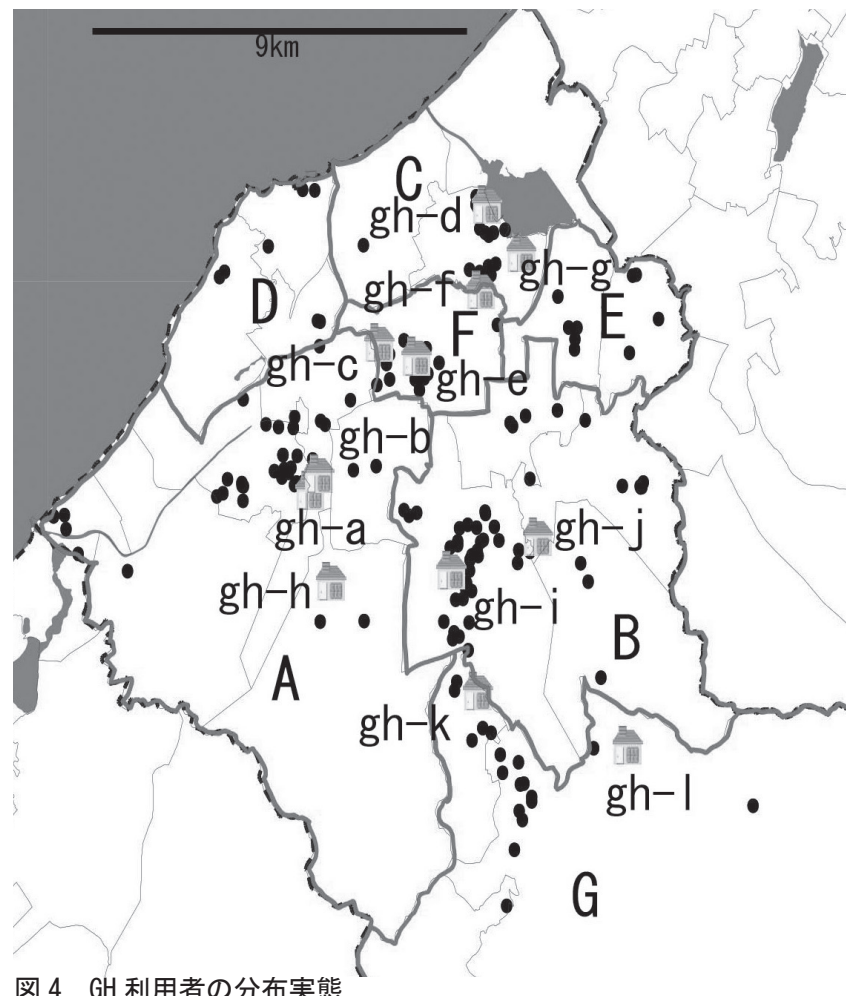

よりやや高い。社人研中位推計によると、今後全国傾向と同じく総 人口は減少し 65 歳以上人口は増加傾向にあると予測されている ${ }^{10)}$ $\mathrm{K}$ 市全体の利用者率 $\alpha \mathrm{K}$ をみると小規模多機能は全国平均よりかな り高く、GH、特養十地域密着型特養は全国平均よりやや高い 8$)$ 。

介護保険事業計画における日常生活圈域は 7 圈域設定されている (圈域 $A \sim G$ とする)。この区分は 1955 年と 2005 年の市町村合併前 表 1 全国と K 市の高齢人口、要介護認定者数、施設利用者数（2013.4）

\begin{tabular}{|c|c|c|c|}
\hline & & 全国 & K市 \\
\hline \multirow{5}{*}{ 人口 } & 総人口（人） & $127,708,000$ & 71,611 \\
\hline & 65 歳以上人口 ( 人) & $29,543,000$ & 20,714 \\
\hline & ( 総人口に占める割合 ) & $23.1 \%$ & $28.9 \%$ \\
\hline & 65-74 歳人口 ( 人) & $15,003,000$ & 10,344 \\
\hline & 75 歳以上人口（人） & $14,540,000$ & 10,370 \\
\hline \multirow{3}{*}{$\begin{array}{l}\text { 要支援· } \\
\text { 要介護 } \\
\text { 詓定数 }\end{array}$} & 65 歳以上認定者総数（人） & $5,564,700$ & 3,597 \\
\hline & 65-74 歳（人） & 693,900 & 381 \\
\hline & 75 歳以上（人） & $4,870,800$ & 3,216 \\
\hline \multirow{3}{*}{$\begin{array}{c}\text { 介護予防 } \\
\text { 介護サービス } \\
\text { 受給者数 }\end{array}$} & 65 歳以上受給者総数 ( 人) & $4,487,400$ & 2,923 \\
\hline & 65-74 歳 (人) & 516,600 & 282 \\
\hline & 75 歳以上 ( 人) & $3,970,800$ & 2,641 \\
\hline \multirow{10}{*}{$\begin{array}{l}\text { 施設 } \\
\text { 利用者数 }\end{array}$} & 小規模多機能 ( 人) & 65,200 & 185 \\
\hline & 利用者率 $\alpha \mathrm{K}$ (mf) & $0.45 \%$ & $1.78 \%$ \\
\hline & GH( 人) & 173,600 & 163 \\
\hline & 利用者率 $\alpha \mathrm{K}$ (gh) & $1.19 \%$ & $1.57 \%$ \\
\hline & 特養（人） & 477,300 & 306 \\
\hline & 利用者率 $\alpha \mathrm{K}(\mathrm{nh}-1)$ & $3.28 \%$ & $2.95 \%$ \\
\hline & 地域密着型特養 (人) & 26,800 & 82 \\
\hline & 利用者率 $\alpha \mathrm{K}(\mathrm{nh}-2)$ & $0.18 \%$ & $0.79 \%$ \\
\hline & 特養＋地域密着型特養（人） & 504,100 & 388 \\
\hline & 利用者率 $\alpha \mathrm{K}$ (nh) & $3.47 \%$ & $3.74 \%$ \\
\hline
\end{tabular}

表 2 日常生活圏域毎の施設定員（人）（括弧内は施設数）

\begin{tabular}{|l|c|c|c|c|r|r|r|}
\hline 圏域 & A & B & \multicolumn{1}{|c|}{ C } & \multicolumn{1}{c|}{ D } & \multicolumn{1}{|c|}{ E } & \multicolumn{1}{|c|}{ F } & \multicolumn{1}{c|}{ G } \\
\hline 75 歳以上人口 & 2,831 & 2,390 & 1,438 & 482 & 814 & 873 & 1,542 \\
\hline 小規模多機能 & $49(2)$ & $43(2)$ & $25(1)$ & $25(1)$ & $18(1)$ & $50(2)$ & $0(0)$ \\
\hline GH & $36(3)$ & $24(2)$ & $45(2)$ & $0(0)$ & $0(0)$ & $36(3)$ & $36(2)$ \\
\hline 特養※ & $102(1)$ & $44(2)$ & $100(1)$ & $0(0)$ & $29(1)$ & $100(1)$ & $65(2)$ \\
\hline
\end{tabular}

※地域密着型特養は $B$ 圏域に 2 箇所、 $E \cdot G$ 圏域に各 1 箇所

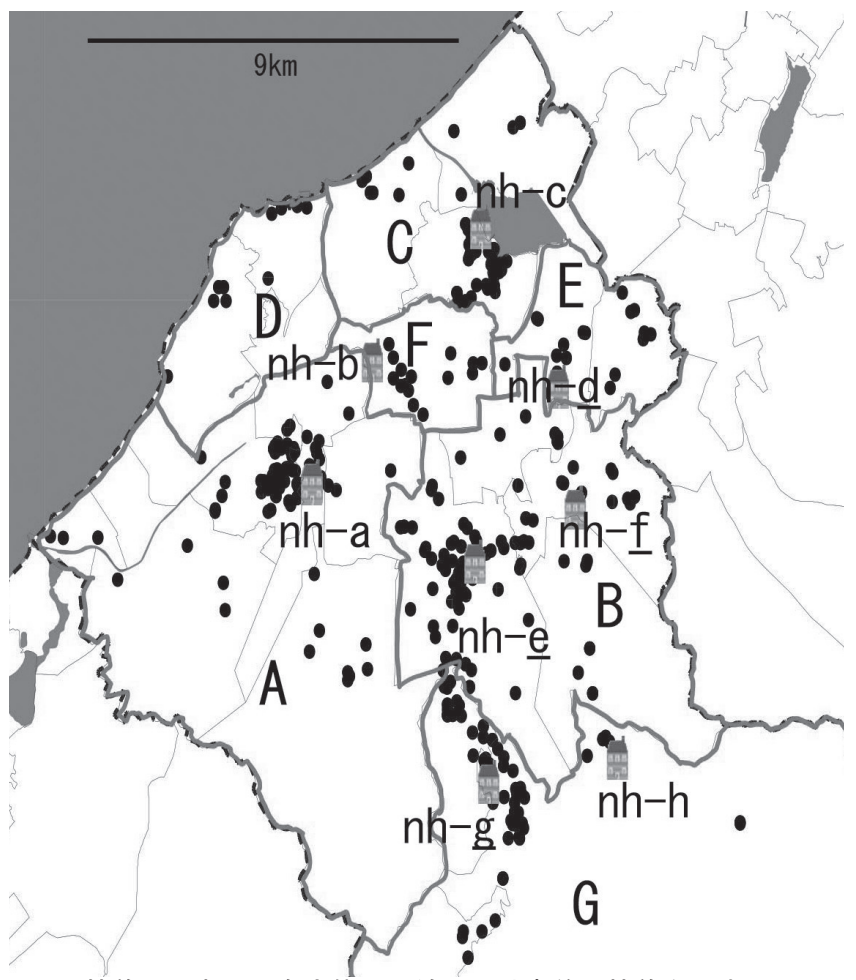

図 5 特養利用者の分布実態（下線は地域密着型特養を示す） 
の旧行政区分に起因するが、2005 年「新 K 市まちづくり計画」にお ける圈域設定と対応している ${ }^{11)}$ 。圈域毎に核となる地域が集約して いる都市構造である。圈域の目安とされる中学校区との対応関係を みると、中学校区は 6 区あり、圈域 $\mathrm{E}, \mathrm{F}$ が二つで 1 中学校区となっ ている以外、ほぼ日常生活圏域と 1 対 1 対応である ${ }^{12)}$ 。従って、ほ ぼ目安どおり中学校区を圈域とする保険者である。なお前述の中山 ら（2007）の全国調査によると、複数圈域を設定する場合の目安と して最も多いのが旧行政区であり、2 番目が中学校区である ${ }^{6)}$

表 2 に各圈域の 75 歳以上人口と各施設種別の定員と施設数を示 す。 2013 年 4 月時点で、小規模多機能は 6 圈域、GH は 5 圈域、特養 (地 域密着型含む）は 6 圈域に整備されていた。

\section{2-3. 事例考察の方法}

事例考察対象は K 市内の小規模多機能全 9 施設、GH 全 12 施設、 特養全 8 施設（うち4 施設は地域密着型）の利用状況である注2) 小規模多機能と GH は地域密着型サービスであり、利用者は原則と して設置圈域内に限られる。一方、特養は広域型施設であり、その 計画単位は老人福祉圈域であるが、一部、地域密着型特養も導入さ れている。そのため特養は小規模多機能と GH の比較参照対象とし て位置づける。

$\mathrm{K}$ 市から上記 3 施設種の全利用者の現住所又は入所前住所に関す る悉皆情報を入手した（2013.4.1 時点のもの）。この情報を GIS 地 図化し、3 施設種別に各圈域内でのサービス利用発生者数、圈域内 外施設の利用者数等を計測した。

図 $3 \sim 5$ は小規模多機能利用者の居住地分布、 $\mathrm{GH}$ ・特養利用者 の入所前居住地分布（）を示す。また $\mathrm{mf}-\mathrm{a} \sim \mathrm{i}$ が小規模多機能、 gh-a 〜 1 が GH、nh-a 〜 h が特養の位置を示す。

\section{3. 小規模多機能・GH・特養の施設選択の実態}

本章では小規模多機能・GH・特養の利用状況を $\mathrm{K}$ 市の圈域単位で 分析する。

3-1. 圏域 $i$ 内 75 歳以上人口Pi75+ と出現施設利用者数 Ui の関係

まず 75 歳以上人口Pi $75+$ と出現施設利用者数 Ui の相関係数は、 小規模多機能 0.85、GH 0.93、特養（密着型特養含む。以下同じ） 0.96 となり、いずれも強い正の相関がみられた。従って圈域 $\mathrm{i}$ 内 65 歳 以上人口のかわりに圈域 $\mathrm{i}$ 内 75 歳以上人口 Pi75+を用いることは 妥当と判断される。

図 6 は圈域別・施設種別の利用者率 $\alpha i=\mathrm{Ui} / \mathrm{Pi} 75+(\times 100)$ を 示す。各施設種とも利用者率は圈域によってかなりばらつきがみら れる。但し、圈域内に施設が一つもない圈域 $D$ での $\mathrm{GH}$ と特養、圈 域 $\mathrm{E}$ での $\mathrm{GH}$ 、圈域 $\mathrm{G}$ での小規模多機能の利用者率は比較的低い。

これをさらに詳しくみるため、図 7 に圈域別・施設種別に出現施 設利用者数 Ui $=$ Pi $75+\times \alpha$ i 想定施設利用者数Pi75+ $\times \alpha$ K で除 した指標を示寸。結局これは $\alpha$ i / $\alpha$ K であるから折れ線はいずれ も図 6 と相似形になるが、市全体值を 1.0 としたときの各值の相対 的なズレが把握しやすい注3)。

圈域毎にみると、3 施設種とも整備されている圈域 $\mathrm{A}, \mathrm{B}, \mathrm{C}$ はほぼ 市全体值 $1.0 \pm 0.2$ の範囲内に収まっており、3 施設種の最大值と 最小值の差も比較的小さい。しかし圏域 F の み、小規模多機能と $\mathrm{GH}$ は市全体值より大きいが特養はかなり小さく、3 施設種の最大值と 最小值の差が大きい。

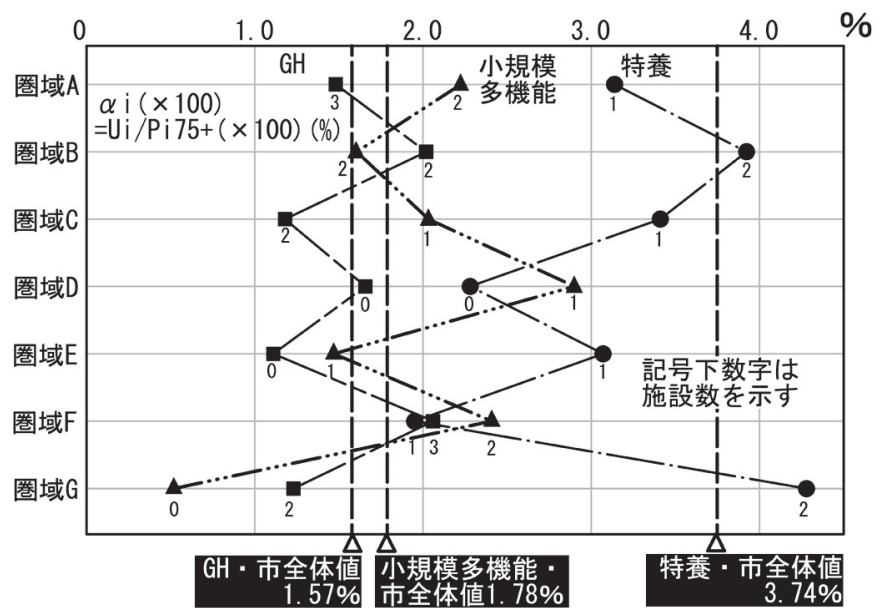

図 6 圏域別・施設種別の利用者率 $\alpha \mathrm{i}(\times 100)(\%)$

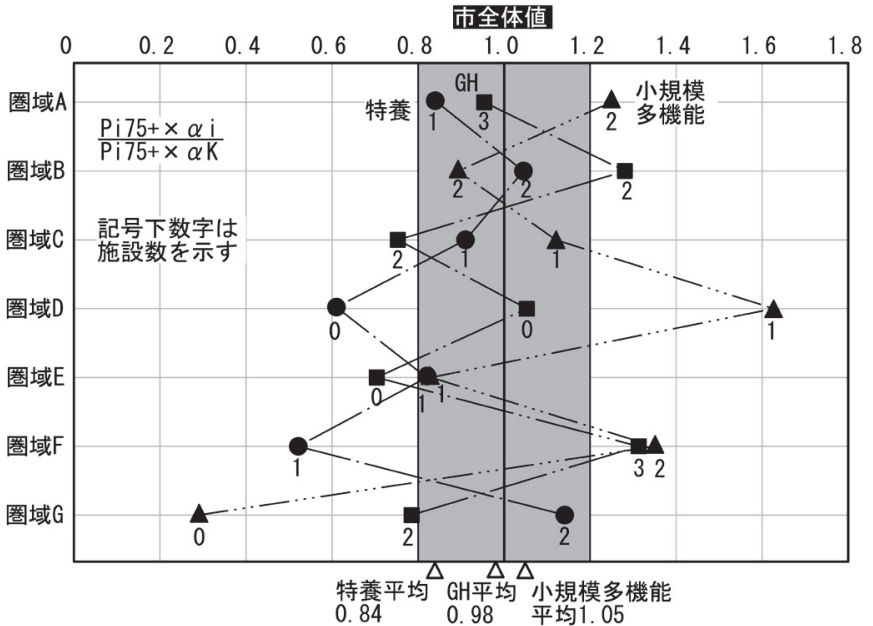

図 7 圏域別 - 施設種別の出現施設利用者数 / 想定施設利用者数



図 8 圏域別・施設種別の選択率 $\beta \mathrm{i}(\times 100)(\%)$

一方、何らかの施設がない圈域は D, E, G である。まず圈域 D では 施設のない特養の值が小さく、小規模多機能の值が市全体值を大き く上回るため、両值の差が大きい。この要因として圈域 D には小規 模多機能しかないためと考えられる。圈域 G では施設のない小規模 多機能の值がかなり小さいため、施設のある特養の值との差が大き い。但し、GH と特養の值は市全体值 $1.0 \pm 0.2$ 範囲内にほぼ収まっ ているため、それらは市全体值とほぼ同じといえる。以上の例では、 異種施設間で何らかの補完関係の存在が示唆される。しかし、圈域 E の場合、施設のない $\mathrm{GH}$ の值は小さいが、施設のある GH と特養の 值も市全体值よりやや小さいため、3 施設種の最大值と最小值の差 


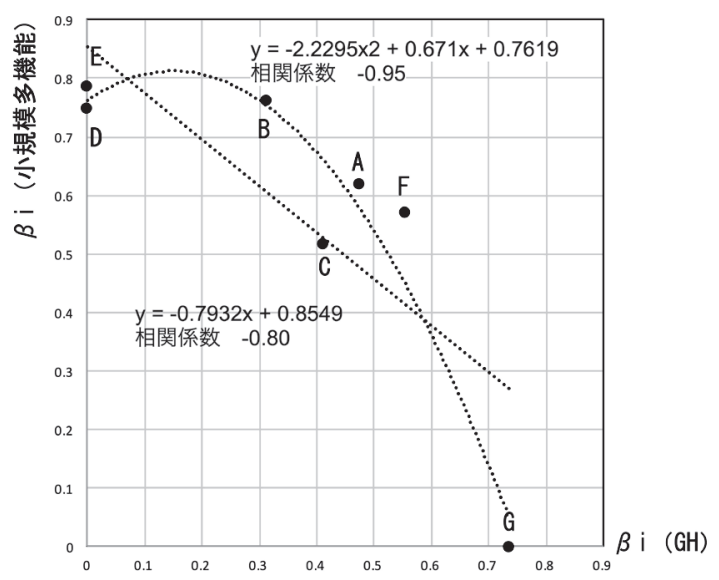

図 9 圏域別・GH と小規模多機能の選択率 $\beta$ i の関係

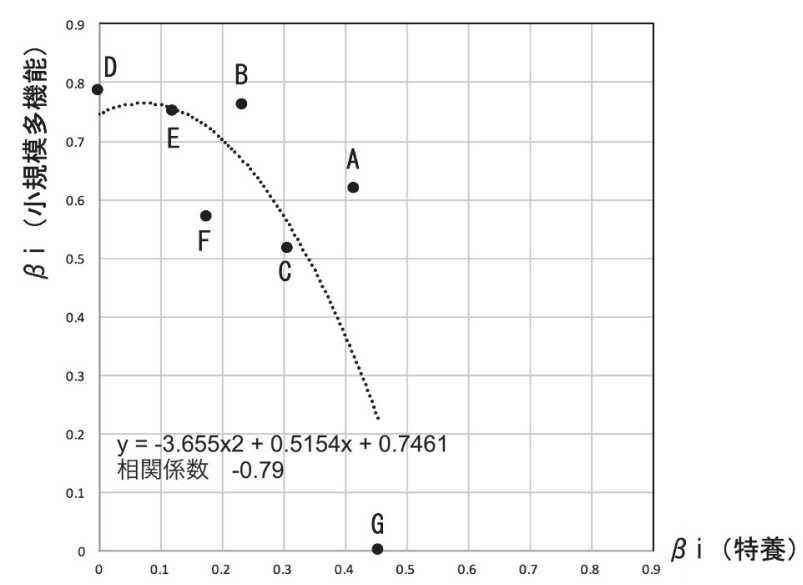

図 10 圏域別 - 特養と小規模多機能の選択率 $\beta$ i の関係

が小さい。

図 6 でみた圈域 D の特養、圈域 $\mathrm{E}$ の $\mathrm{GH}$ 、圈域 $\mathrm{G}$ の小規模多機能 の值を図 7 でみると、0.8 未満とたしかに市全体值に比べて小さい。 しかし圈域 D の GH はほぼ 1.0 であり、市全体值と同等である。つ まり施設がない 4 事例中 3 事例では確かに利用者率が比較的低かっ たが、必ずしも利用者率が低くなるとは限らない。換言すれば、圈 域内に施設が 1 つもない場合、利用者率が低くなることが多い、と しか言えない。

\section{3-2. 選択率 $\beta i=u i(i n) / U i$ の実態}

図 8 は圈域別・施設種別の選択率 $\beta i(\times 100)$ を示す。まず選 択率 $\beta \mathrm{i}(\times 100)$ の $\mathrm{K}$ 市全体での平均值は、小規模多機能 $62.2 \%$ 、 GH41. $0 \%$ 、特養 $31.3 \%$ であった。小規模多機能は施設がない圏域 G 以外の全てで選択率 $\beta$ i $(\times 100)$ が $50 \%$ 以上である。小規模多機 能は空きがある状況であることから、この值は利用者の量的ニー ズが素直に反映された結果と判断される。一方、特養は施設があっ ても選択率 $\beta$ i $(\times 100)$ が 30\%未満の圈域が 3 つあるGH は施設 整備された 5 圈域中 4 圈域において選択率 $\beta$ i $(\times 100)$ が 31.3 $55.6 \%$ であり、特養と小規模多機能の中間的状態である。入所施 設と通所施設という区分で比較すると、通所施設の方が選択率 $\beta$ i ( × 100) が 50\%以上の圈域が多い。一方、入所施設では GHより 特養の方が選択率 $\beta$ i $(\times 100)$ が 30\%未満の圈域が多い。

次に選択率 $\beta$ i と各指標の相関を調べたが、 3 施設種とも 75 歳以



図 11 圏域別 - GH と特養の選択率 $\beta$ i の関係



図 12 圏域別 - 入所系 $(\mathrm{GH}+$ 特養) と小規模多機能の選択率 $\beta \mathrm{i}$ の関係

上人口Pi75+、内在率 ui (in) / F i 、想定利用者数Pi $75+\times \alpha$ K との 間に相関はなかった。一方、 $\mathrm{GH}$ で選択率 $\beta$ i と実態整備率 $\mathrm{Ci} / \mathrm{Ui}$ と の間の相関係数が 0.77 、想定整備率 $\mathrm{Ci} /(\mathrm{Pi} 75+\times \alpha \mathrm{K})$ との間で 0.77 、 圈域 $\mathrm{i}$ 内施設定員数 $\mathrm{Ci}$ との間で 0.88 と強い正の相関がみられた() とする)。なお特養と小規模多機能では今回検討した指標の中には 選択率 $\beta$ i を関数化しうる指標はなかった。

図 8 を圈域別にみると、3 施設とも整備されている圈域 $\mathrm{A}, \mathrm{B}, \mathrm{C}, \mathrm{F}$ では割合の差はあるものの選択率 $\beta$ i は必ず特養 $<\mathrm{GH}<$ 小規模多 機能の順に大きくなる。すなわち広域型施設よりも地域密着型施設 の方が高く、また入所施設よりも通所施設の方が高い傾向にある。 これは通所施設に待ちがなく入所施設に待ちがあるという現況や、 GH は地域密着型施設である一方、特養は広域型施設であるという役 割分担を反映しているものと考えられる。

\section{3-3. 異種施設間の選択率 $\beta$ i の相関}

図 8 をよくみると、小規模多機能のない圏域 $\mathrm{G}$ では $\mathrm{GH}$ の選択率 $\beta$ i が非常に高く、GH のない圈域 D, E では小規模多機能の選択率 $\beta$ i が非常に高い。つまり異種施設間で何らかの相関性が示唆される。 そこで図 $9 \sim 12$ は各圈域内での 2 施設種間の選択率 $\beta$ i の相関関 係をみたものである。図 9 で、 $\mathrm{GH}$ と小規模多機能は二次近似で相関 係数 -0.95 と強い負の相関がある(1)とする)。これについて、両 施設が圈域内の認知症高齢者対応等を分担する相互補完性があると いう理由が考えられる。一方、図 10 で特養と小規模多機能は二次 
近似で -0.79 と強い負の相関、図 11 で $\mathrm{GH}$ と特養は一次近似で 0.83 と強い正の相関があるが、GH と小規模多機能のものよりは低い。さ らに図 12 で入所系（GH と特養の選択率の和）と小規模多機能の相 関は二次近似で -0.95 と強い負の相関がある (价とする)。ここで も入所系と通所系施設の相互補完性の可能性が考えられる。

3-4. ボロノイ分割による最近隣施設選択率

参考までに施設毎にボロノイ分割線をひいて各領域の利用者数を 計測した。ボロノイ分割はある施設から距離的に最も近い領域を示 すので、領域内で発生した利用者のうち同領域内に存在する施設を 利用している者は最近隣施設を選択していることになる。図 13 に この最近隣施設を選択する割合（最近隣施設選択率とする）を示 す。小規模多機能では最小 $21.4 \%$ 最大 $62.5 \%$ まで、GH では最小 $12.5 \%$ 最大 $100 \%$ まで、特養では最小 $4.5 \%$ 最大 $41.7 \%$ まで拡 がっていた。特養では地域密着型の方が広域型より最近隣施設選択 率が低くなったが、その理由は不明である。そして最近隣施設選択 率の平均值は、小規模多機能 $44.2 \%$ 、GH32. 3\%、特養 $23.0 \%$ であった。

\section{3-5. 圏域間の移動の実態}

図 14 は施設利用のための圈域間の移動の実態イメージを示す。 矢印は各施設種別に K 市内での利用者数全体 (Ui から K 市の住所地 特例者数 ui (out, outK) を減じた人数) を 100 とした指数で 3.0 以 上を段階的に太く表記した。矢印の多さ、つまり移動の多さは特養 $>\mathrm{GH}>$ 小規模多機能となっている。次に矢印の向きをみると、太 い矢印は実態整備率 Ci/Ui（× 100）（圈域脇右側の数）が 100\%超 の圈域 (白抜き表記)、つまり出現施設利用者数よりも整備数が多 い圏域に向かっている。

広域型と地域密着型という区分でみると広域型の方が圈域間移動 が多く、隣接圈域を飛び越した利用も多い。また入所施設と通所施 設という区分でみると、入所施設の方が移動が多い。この要因とし

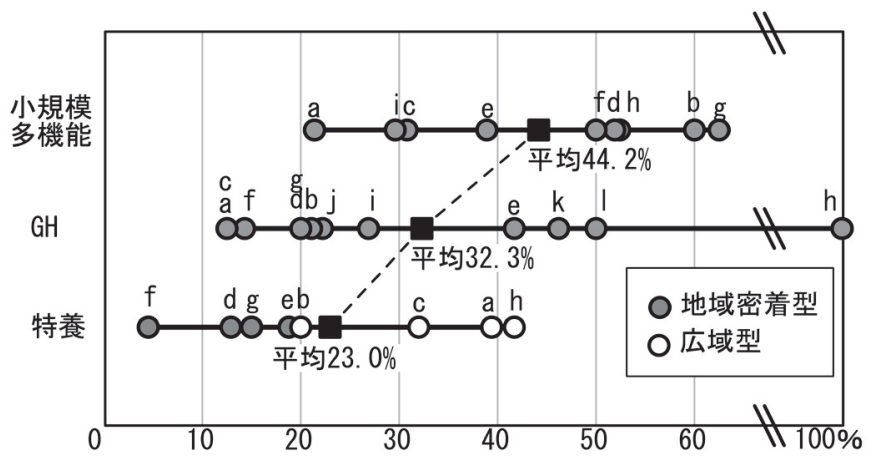

図 13 施設種別のボロノイ分割による最近隣施設選択率 (\%)

て入所施設である GH と特養は満床のため、空きがあれば圈域にか かわらず入所しているためと考えられる。このため、3-2 において、 $\mathrm{GH}$ の選択率 $\beta$ i の平均值は小規模多機能のそれに比べてやや低く なったものと思われる。

さらに圈域別にみると圈域 $\mathrm{i}$ 内 75 歳以上人口 P i $75+$ が比較的多 いのは圈域 A, B である。特に圈域 B では内在率 ui (in)/Fi が 3 施設 種とも50\%以上（グレーハイライト表記）であり、他圏域に移動す る者も多い。一方、圈域 $\mathrm{F}$ は K 市中心部に位置し施設が集中的に整 備されており、実態整備率が 3 施設とも高い。そのため他圈域から の利用が多いと考えられる。

以上、圈域内・間移動をあわせてみると、地域密着型かつ通所 施設である小規模多機能は施設整備された 6 圈域全てで選択率 $\beta$ $i(\times 100)$ が $50 \%$ 以上となり、圈域間移動も比較的少ない。一方、 広域型かつ入所施設である特養では選択率 $\beta$ i $(\times 100)$ が $30 \%$ 未 満の圈域が 3 つみられ、圈域間移動も多い。さらに地域密着型かつ 入所施設である GH は、小規模多機能よりも選択率 $\beta$ i $(\times 100)$ が $50 \%$ 以上の圈域は少なく、圈域間移動も若干増えており、小規模多

\section{凡例 \\ 1) 各圏域を示す口 \\ 中の数字 : K市全体を 100 とした、75歳以上人口の構成比（\%) \\ 枠線の太さ : 太いほど75歳以上人口が多い \\ 点線の枠：当該施設種がない圏域 \\ 枠内の色：選択率 $\beta \mathrm{i}(\times 100) \geqq 50 \%$ \\ $50 \%>$ 選択率 $\beta$ i $(\times 100) \geqq 30 \%$ \\ 選択率 $\beta \mathrm{i}(\times 100)<30 \%$}

2) 圏域間の矢印：移動を示す

矢印の太さ: 太いほど人数が多い

点線の矢印：隣接圏域を飛び越した移動

3）各圏域の脇の数字

内在率 ui (in)/ Fi $(\times 100)(\%) /$ 実態整備率 Ci/ Ui $(\times 100)(\%)$

実態整備率が $100 \%$ を超える場合：白抜き表記（例） 204.1

内在率が $50 \%$ 以上の場合：グレ一ハイライト表記 (例) 50.0

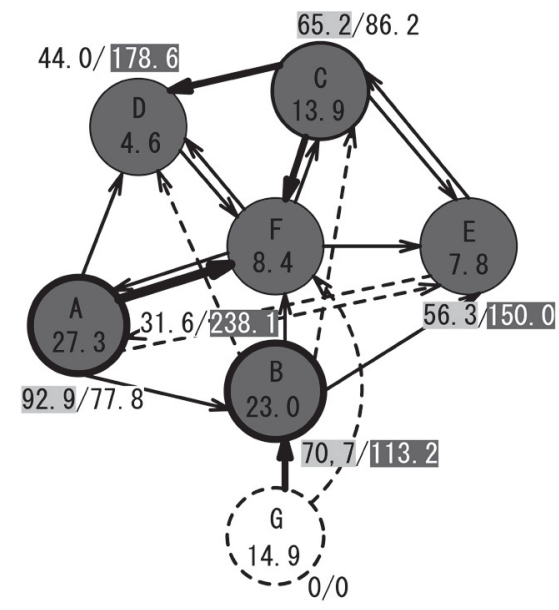

小規模多機能

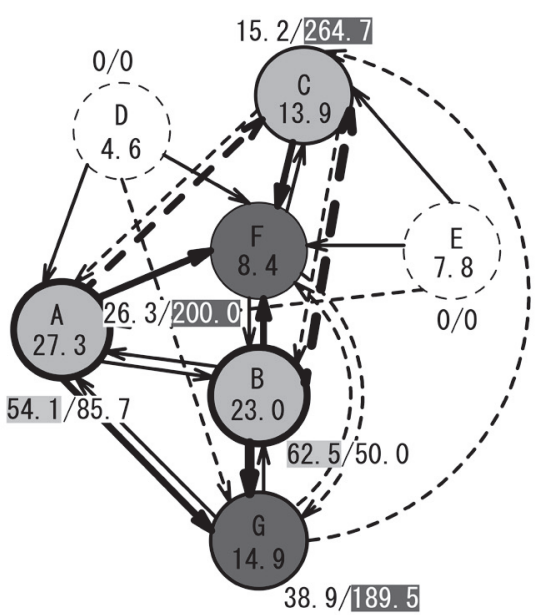

GH

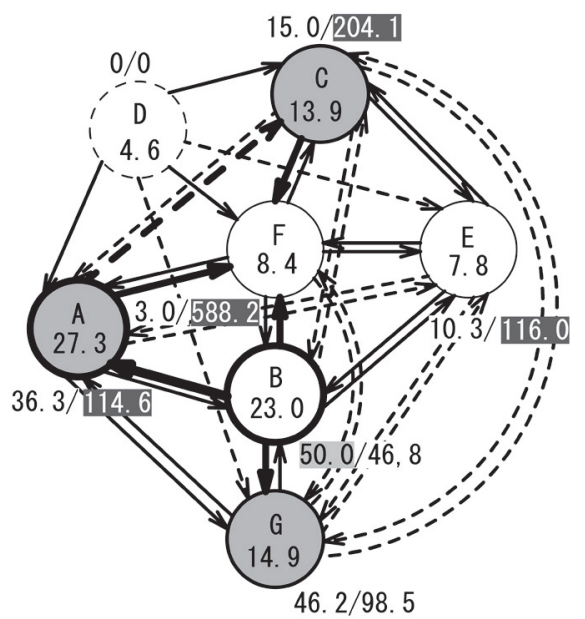

特養

図 14 施設利用のための圏域内・間移動の実態イメージ 
機能と特養の中間に位置する。

\section{3-6. 圏域 $\mathrm{i}$ 内の施設利用者数 Fi の構成の実態}

図 15 は施設種別、圈域別にみた施設利用者数Fi の構成と実態整 備率の関係を示す。GH と特養に旧住所不明者がいるが、いずれも K 市内からの入所者であった。このため旧住所不明者は、本来、自圈 域内利用者数 ui (in) 又は K 市内他圈域からの利用者数 oi (inK) に 算入されるべき人である。これをふまえると、小規模多機能の利用 者構成は自圈域内利用者数 ui (in) と K 市内他圈域からの利用者数 oi (inK) による二層構成であり、GH と特養の利用者構成は上記 2 者 に他市町村からの住所地特例者数 oi (outK) を加えた三層構成となっ ている。但し、それらの構成比率は施設種別、圈域別でばらつきが 大きい。なお地域密着型サービスの GH には他市町村からの住所地 特例者数 oi (outK) がいないはずであるが、平成 18 年の地域密着型 サービス移行前からの経過措置により若干名残存していた。

圈域別の利用者構成比率のばらつきの原因を探るため、内在率 $\mathrm{ui}$ (in) / Fi と各種指標との間の相関をみたところ、内在率と 75 歳以 上人口Pi75+、想定利用者数P $i 75+\times \alpha$ K との間に強い正の相関が みられた。つまり圈域内 75 歳以上人口が多いほど、圈域内の施設 利用者数に占める自圈域内利用者数の割合が高い。一方、内在率と 想定整備率 $\mathrm{Ci} /(\mathrm{Pi} 75+\times \alpha \mathrm{K})$ 、実態整備率 $\mathrm{Ci} / \mathrm{Ui}$ との間に強い負 の相関がみられた。つまり圈域内の想定又は出現施設利用者数に対 する施設整備数の割合が低いほど、圏域内の施設利用者数に占める 自圈域内利用者数の割合が高い。まとめると、自圈域内利用者数の 割合は、75 歳以上人口が多いほど、或いは施設整備率が低いほど、 高くなる傾向が強い。図 15 では、これらの逆相関関係がわかりや すいように実態整備率を示寸折れ線グラフを原点を反転して描画し た。その結果、 3 施設種とも自圈域内の施設利用者数の割合を示す 黒い棒グラフの凹凸と実態整備率を示寸折れ線グラフがほぼ相似形 となっていることが読み取れる。

\section{4. 選択率 $\beta$ i の近似式化}

以上の考察から選択率 $\beta$ i の近似式化を試みる。

まず 3-2. 円より、選択率 $\beta$ i は、GH の圈域 $\mathrm{i}$ 内施設定員数 ( $\mathrm{Ci}$ (gh) とする）との間で強い正の相関がみられた。GH の選択率を $\beta$ i ( gh) とすると、下式により $\mathrm{Ci}(\mathrm{gh})$ から $\beta$ i (gh) の近似值が求められる。 $\beta$ i $(\mathrm{gh})=0.0132 \mathrm{Ci}(\mathrm{gh})+0.0212$

また 3-3. (1)上り、同一圈域内の小規模多機能と GH の選択率 $\beta$ iの間には強い負の相関がみられた。小規模多機能の選択率を $\beta$ i (mf) とすると、図 10 より、その近似式は

$\beta$ i (mf) $=-2.2295 \beta$ i (gh) ${ }^{2}+0.671 \beta$ i $(\mathrm{gh})+0.7619$

上式により $\beta$ i (gh) から $\beta$ i (mf) の近似值が求められる。

さらに3-3. (口より、入所系施設と小規模多機能の選択率の間に 強い負の相関がみられた。図 13 より、その近似式は

$\beta$ i $(\mathrm{mf})=-0.8744 \mathrm{x}^{2}+0.4503 \mathrm{x}+0.7493$,

$\mathrm{x}=\beta \mathrm{i}(\mathrm{nh})+\beta \mathrm{i}(\mathrm{gh}), \mathrm{X}>0, \beta \mathrm{i}(\mathrm{nh})>0$

上式により $\beta$ i (gh) と $\beta$ i (mf) を用いて、特養の選択率 $\beta$ i (nh) の近似值が求められる。

\section{5. まとめ}

本研究では、ある地方都市 $K$ 市において日常生活圈域単位でみた

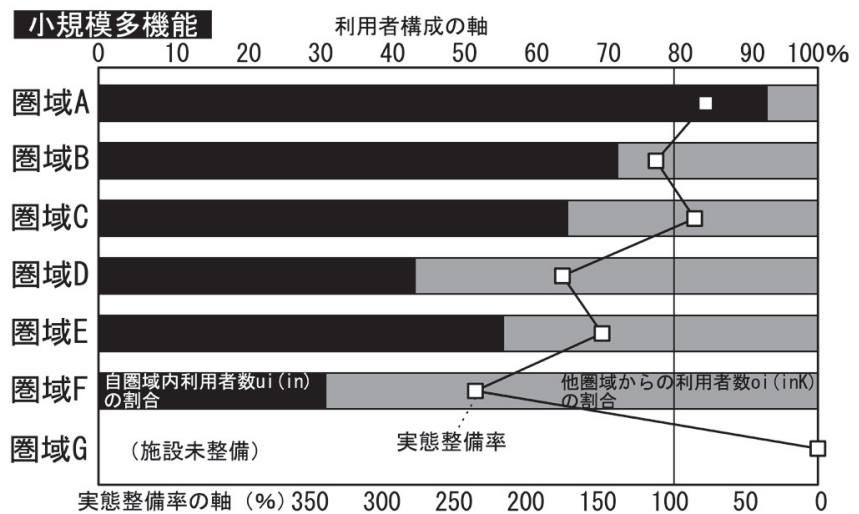

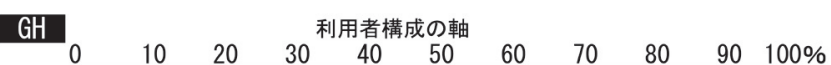
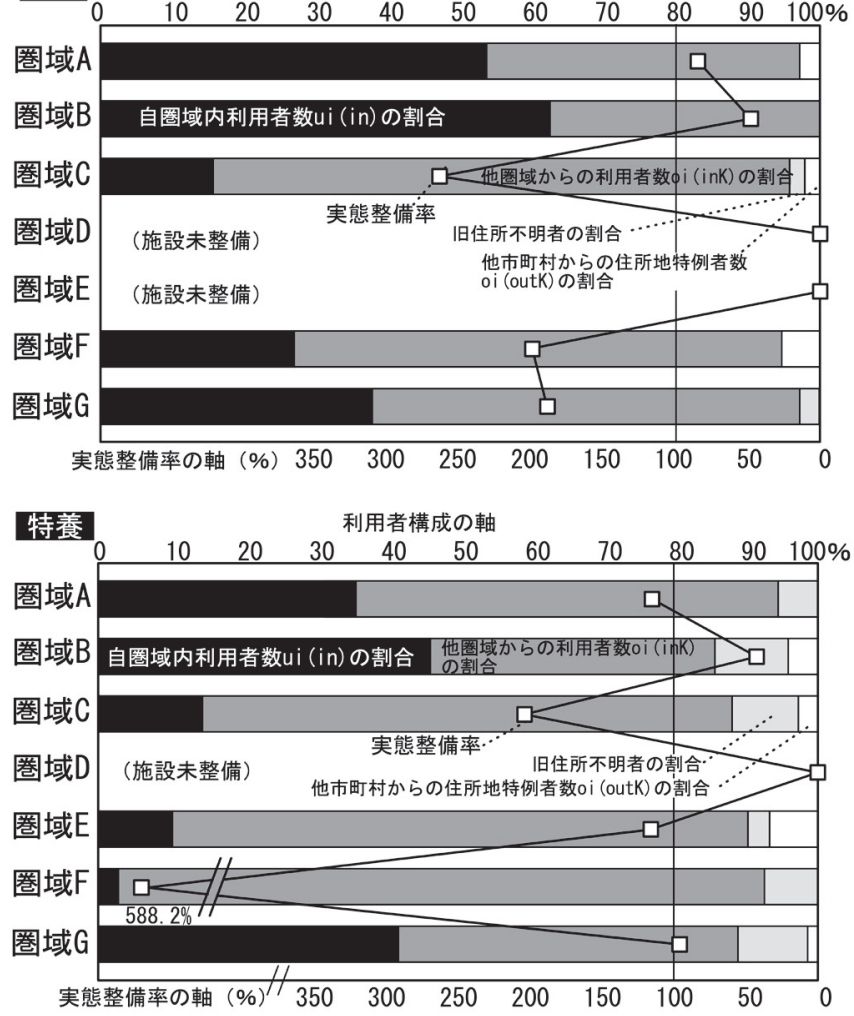

図 15 施設種別 - 圏域別施設利用者数 $\mathrm{Fi}$ の構成と実態整備率の関係

高齢者福祉施設の選択の実態を明らかにし、自らの居住する日常生 活圏域内の施設を選択する割合（選択率 $\beta$ i）算出の近似式化を試 みた。そして次の点が明らかになった。

<選択率 $\beta$ i について>

- 選択率 $\beta$ i $(\times 100)$ の $\mathrm{K}$ 市全体での平均值は、小規模多機能 62.2\%、GH41.0\%であり、施設選択の実態が明らかになった。広域 型施設の特養ではさらに低かった。

・小規模多機能、GH、特養の 3 施設種とも整備されている圈域では、 選択率 $\beta$ i は必ず特養 $<\mathrm{GH}<$ 小規模多機能の順に大きくなる。つ まり広域型よりも地域密着型の方が高く、また入所施設よりも通所 施設の方が高い傾向にある。

・地域密着型かつ通所施設である小規模多機能は施設整備された 6 圏域全てで選択率 $\beta$ i $(\times 100) 50 \%$ 以上となり、圏域間移動も比 較的少ない。一方、広域型かつ入所施設である特養では選択率 $\beta$ i ( × 100) 30\%未満の圈域が 3 つられ、圏域間移動も多い。さら に地域密着型かつ入所施設である GH は、小規模多機能よりも選択 
率 $\beta$ i ( × 100) 50\%以上の圈域は少なく、圈域間移動も若干増えて おり、小規模多機能と特養の中間に位置する。

$<$ 自圈域内利用者数の割合と利用者率について $>$

- 圈域 $\mathrm{i}$ 内の施設利用者数 Fi の構成をみると、自圈域内利用者数の 割合は、75 歳以上人口が多いほど、或いは施設整備率が低いほど、 高くなる傾向が強い。

・しかし、圏域内に施設が 1 つもない場合、75 歳以上人口に対する 利用者数の割合 (利用者率) そのものが低くなることが多い。

＜選択率 $\beta$ i の近似式について>

- $\mathrm{GH}$ の選択率 $\beta \mathrm{i}(\mathrm{gh})$ は圈域 $\mathrm{i}$ 内施設定員数 $\mathrm{Ci}(\mathrm{gh})$ との間で強い 正の相関がみられた。

- 異種施設間の関係として、GH と小規模多機能の選択率 $\beta$ i は非常 に強い負の相関がある。両施設が圏域内の認知症高齢者対応等を分 担する相互補完性があるためと考えられる。また入所系施設と小規 模多機能の選択率 $\beta$ i は強い負の相関がある。

- 以上の関係をもとに小規模多機能、GH、特養の選択率 $\beta \mathrm{i}$ 算出の 近似式を求めた。

\section{謝辞}

本研究を遂行するに当たり貴重な資料をご提供いただいた K 市に感 謝申し上げます。また本研究は神取萌子氏の平成 26 年度金沢大学 卒業論文「高齢者施設サービス需要の地理的分布推計方法に関する 研究」を大幅修正したものです。これは平成 26 年度地域保健総合 推進事業「保険者を単位地域と寸る高齢者の要介護（支援）需要構 造の動態的解析および要介護（支援）高齢者のサービス受益圈域の 設定に関する研究」（分担事業者 松本啓俊）の一部です。
注 1） 2014 年時点で全国の介護予防・介護サービス受給者の約 9 割が 75 歳 以上で、K市（2013 年）でも同様であった（文 8)。そこで小規模多機能、 $\mathrm{GH}$ 、特盖の利用者数を 75 歳以上人口で割った利用者率の全国二次医療圈 毎の值の平均值と $\mathrm{K}$ 市の值を比較した（文 8)。

注 2）介護保険において施設とは特養、老健、療養型施設であり、GH や小規 模多機能は含まないが本研究では一般的意味でこれらを施設と呼称する。

注 3）当該圈域の利用者率と K 市全体での利用者率が同じであれば 1.0、前者 が後者より小さければ 1.0 未満、大きければ 1.0 より大となる。

\section{参考文献}

1) 厚生労働省 HP, http://www. mhlw. go. jp/, 2015. 2.17 参照

2）広井良典：人口減少社会という希望，朝日新聞出版，2013

3）竹谷修一, 上田陽三ほか：北海道における高齡者医療・福祉施設の体系的 整備に関する研究 - 老人受療園及び特養入所圈域の比較検討, 日本建築学 会大会学術講演梗概集 E, pp. 507-508, 1993.7

4）助川政司, 藤本信義ほか：宇都宮市における福祉圈域の設定 - 高齢者 福祉施設のあり方に関する研究その 1 , 日本建築学会大会学術講演梗概集 E, pp. 525-526, 1991.8

5）奥山純子，中山徽ほか：介護サービス基盤の圈域設定計画とその整備手法 一地方自治体における高齢者福祉施設の配置計画その 2 , 日本建築学会技術 報告集第 24 号，pp. 381-386，2006. 12

6) 大高牧子, 中山徽ほか：全国の自治体における日常生活圈域設定の実態 高齢者の地域居住を保障する基盤整備に関する研究その 1 , 日本建築学会 大会学術講演梗概集, F-1, pp. 931-932, 2007.7

7）西野辰哉：ある地方都市における高齢者の日常生活圈域の実態とその比 較，日本建築学会計画系論文集，No. 728，pp. 2117-2127，2016.10

8）西野辰哉: 2010 年の介護保険関連施設利用者率からみた 2025 年改革モデ ルの検証とその定量的整備指標の応用可能性，日本建築学会計画系論文集 No. 721， pp. 559-567，2016.3

9) K 市市民部長寿課 : 平成 $24 \sim 26$ 年度 K 市高齢者福祉計画・K市介護保険事 業計画, 2012.3

10) 国立社会保障 - 人口問題研究所: 日本の将来人口推計 (平成 24 年 1 月推計) 出生中位 (死亡中位) 推計

11)K 市新市建設計画 : 新 K 市まちづくり計画, 2005

12）学校教育情報サイト: http://www. gaccom. jp/search/p17/c206_public_ js/, 2015.2.17 参照 


\title{
ACTUAL CHOICES OF FACILITIES FOR THE ELDERLY IN ACCORDANCE WITH 'DAILY LIVING AREAS' IN A PARTICULAR MUNICIPALITY
}

\author{
Tatsuya NISHINO* \\ * Assoc. Prof., School of Environmental Design, College of Science and Engineering, Kanazawa University, Dr. Eng.
}

\section{Objective}

This study was aimed at regulating an approximate formulation of the selection rates of facilities for the elderly based on the actual choices of facilities in accordance with 'daily living areas', which is defined as care service providing districts by local government, in a particular municipality.

\section{Methods}

A case study was conducted for the usage situation of 9 community-based multi-care facilities, 12 group living facilities (group homes) for the elderly with dementia, and 8 intensive-care homes for the elderly (nursing homes) in Municipality K, Ishikawa Prefecture. For this purpose, all information regarding current address and address before admittance to the facilities of all users of the above three kinds of facilities was obtained from Municipality K(as of April 1, 2013). The information was mapped using GIS to measure and analyze the incidence of users of services in each area and users of facilities within and outside the areas for the different 'daily living areas', according to the type of facility.

\section{Results and Discussion}

The following observations and conclusions were made:

- The overall average rates for the selection of facilities within the 'daily living areas' was $63.8 \%$ for community-based multi-care facilities, $38.5 \%$ for group living facilities, and $31.3 \%$ for nursing homes.

- In the area where three kinds of facilities were established, average rates for the selection area always became larger in the order of nursing homes, group living facilities, and community-based multi-care facilities. The overall average selection rates were higher for community-based facilities than for facilities covering wide areas and higher for outpatient care facilities than for inpatient care facilities.

- In terms of movements within and between 'daily living areas', selection rates for small multi-care facilities, which are community-based and provide outpatient services, were $50 \%$ or higher in all areas where such facilities are available, indicating that movements between different 'daily living areas' were relatively few. However, selection rates for nursing homes, which cover wide areas and provide inpatient services, were found to be lower than $30 \%$ in three areas, indicating that there was a high incidence of movements between different 'daily living areas'. Furthermore, selection rates for group living facilities, which are community-based and provide inpatient services, were intermediate between those for nursing homes and community-based multi-care facilities.

- The larger the 75-years-or-older population was or the lower the actual establishment rate of facilities was, the ratio of users from within the area tended to be higher. However, if there was no facility in the area, the ratio of facility users for the 75-years-or-older population itself tended to become lower.

- Only the selection rate for group living facilities was found to have a strong positive correlation with the capacity limit of the facility within the living area.

- A strong negative correlation was found between the selection rate for group living facilities and that for community-based multi-care facilities. This is possible because they are in complemental relation for the care of the elderly with dementia in the area. A strong negative correlation was found between the selection rate for inpatient facilities and that for community-based multi-care facilities.

- An approximate formulation of the selection rates of these three facilities for the elderly in the living area was made on the basis of the above considerations. 